\title{
Learning to Teach: A Descriptive Study of Student Language Teachers in Taiwan
}

\author{
En-Chong Liaw ${ }^{1}$ \\ ${ }^{1}$ Department of Applied Linguistics and Language Studies, Chung Yuan Christian University, Chungli, Taiwan \\ Correspondence: En-Chong Liaw, Department of Applied Linguistics and Language Studies, Chung Yuan \\ Christian University, Chungli, Taiwan. Tel: 011-886-03-2656660. E-mail: liawec@cycu.edu.tw
}

\author{
Received: October 12, 2012 Accepted: October 30, 2012 Online Published: October 31, 2012 \\ doi:10.5539/elt.v5n12p152 URL: http://dx.doi.org/10.5539/elt.v5n12p152
}

\begin{abstract}
Studies have shown that many training programs are relatively ineffective in preparing prospective teachers for classroom teaching. Such findings suggest that teacher training programs might require improvement and that prospective teachers should be more thoroughly assessed during the training period. This study examined the learning process of a group of EFL teachers during their practicum at elementary schools. Our findings indicate that prior language learning experience and peer student teachers play a critical role in this period. Overall, the results suggested that student teachers would benefit from greater integration between field experiences, practicum, and lecture courses, which would enable the students to link teaching theory and practice more effectively.
\end{abstract}

Keywords: EFL, teacher training, teaching practicum, student teacher, teaching technique, teacher belief

\section{Introduction}

Numerous studies have been conducted with student teachers to explore various issues. Research topics have included program design, changes in teacher perspectives and attitudes during the training period, and the implementation of innovative techniques or technology. Results from these studies provide fresh ideas and hope for improved teacher education. However, several studies have indicated that training programs may be relatively ineffective in preparing prospective teachers for classroom teaching (Hwang, 1996; Leu, 1997). Such findings suggest that current teacher training programs might be deficient in some areas, and that better assessment of prospective teachers is needed during the training period. The relationship between course work and personal changes during the training period deserve greater attention.

The process of learning to teach requires rigorous effort from both the student teachers and the trainers. This process constitutes a conceptual transformation in which student teachers reconstruct idealized or inappropriate ideas of learning and teaching. Various concerns and stages have been identified as indicators of conceptual transformation. According to Fuller (1969), teachers develop typical concerns during the process of professional development, such as concerns with self, teaching tasks, and effect. Novice teachers are particularly self-conscious and concerned with evaluations by administrators, and with gaining acceptance from their students and colleagues. As their length of teaching experience increases, their attention shifts to the effectiveness of their delivery of content and its effect on student learning. Occasionally, teachers become concerned with the pedagogical beliefs and values that they bring to their classrooms, based on their personal preferences and prior experience as students.

The most widely adopted model of teacher development is that of Kangan (1992), who views teachers' professional development as a reciprocal relationship between prior learning (memories) and the training process. Kangan emphasizes the changes in aspects such as metacognition and the teacher's perception of pupils. Student teachers gradually develop a better understanding of their pupils and of their own roles as teachers. They become aware of changes in their own knowledge and beliefs, and shift their focus from self-absorption to the learners. Moreover, student teachers develop problem-solving skills that can be generalized across contexts. The changes described in Kangan's model require not only input from the training program but also real classroom experiences. These classroom experiences provide a catalyst for the student to become aware of conflicts between his or her beliefs and the actual reality of the classroom. Interaction with the environment, including mentors and fellow teachers, plays an important role in this process of professional socialization. 
This study was referenced on Kangan's (1992) model of teacher development. The study approach was descriptive and examined the experiences of student language teachers receiving training in an EFL context. The research questions were as follows:

How do student teachers perceive language teaching and learning?

What changes and difficulties are encountered over the practicum period?

To what extent do the classroom experience and training program prompt student teachers to change their beliefs during the learning process?

\section{Literature Review}

\subsection{Changes in the Beliefs of Student Teachers}

Concepts of teaching are belief-driven (Chan \& Elliott, 2004), and teachers' beliefs determine their performance and behavior in the classroom. Teachers make decisions and judgments according to the beliefs they bring to the classroom setting. Preconceptions of teaching and learning play a key role in student teachers' comprehension and learning during the training process; such preconceptions tend to resist change strongly. Thus, one of the key goals of teacher training programs is to correct misconceptions. Student teachers attribute their pre-training beliefs to cultural sources, years of experience as language students, models they have previously encountered, or their self-image as a teacher (Fischl \& Sagy, 2005; Korthagen, \& Russell, 1999; Lin, 2008, Lin \& Lucey, 2010). Preconceptions act as a filter through which the theories and information presented during training must pass. In some cases, the preconceptions remain intact and the effect of training is questionable.

Methods for promoting constructive change have been discussed in several studies. Key elements leading to changes in preconceptions have been identified, including events, contexts, and practices encountered during field experiences (such as the practicum). Real classroom experiences provide an environment in which students can testing and re-examine both learned theories and their own pre-existing beliefs. The teacher's personality, cultural background, and strength of beliefs influence how extensive the changes are likely to be (Eliam, 2002; Hennissen et al, 2011). For example, low-risk contexts that provide support and suggestions from supervisors and other student teachers increase the likelihood of change (Hollingsworth, 1989; Tang, 2003). When facing challenges, student teachers are confronted by a mismatch between their beliefs and reality. This conflict generates a tension that places the student in an "unstable equilibrium" (Melnick \& Meister, 2008). The need to move from "disequilibration" to "stable equilibrium" provides the catalyst for belief change.

Busch (2010) suggests that teacher educators should consider the effect of the belief systems of preservice teachers early in the training period. Furthermore, the transfer of skills from a training environment to classroom practice requires the integration of theory and practice (Brouwer, 1989). The student's involvement into a school context and the chance to participate in professional relationships beyond the classroom generate considerable influence in changing beliefs. Unfortunately, such opportunities are limited in most training programs, and social contacts are restricted to the college classroom. This narrowness of the contacts provided in training programs requires revision, if the final goal of changing student teachers' beliefs is to be realized.

\subsection{Effect of Training and Teacher Education Programs}

Teacher training programs generally aim at improving teachers' use of their pedagogical knowledge and familiarity with effective teaching methods (Begle, 1979; Goldhaber \& Brewerm, 2000). Training courses and field experience comprise the two key elements of most training programs. Theories and concepts discussed during training represent "knowledge for teachers", which refers to the knowledge and skills needed for teacher certification. By contrast, field experiences such as the practicum provide professional contexts for teachers to develop their self-image as teachers (Xu \& Connelly, 2009). Prospective teachers require information on specific subject content and the learning context in addition to general teaching skills (Bransford, Darling-Hammond \& LePage, 2005; Wilson et al, 2001). Mentoring during the practicum helps students to develop teaching competence, and mentor dialogue during the practicum provides emotional support and guidance to student teachers as they struggle with the disjoint between theory and reality (Lindgren, 2005; Marable \& Raimondi, 2007). Regardless of the curriculum design and pedagogical content, all training programs aim at changing the beliefs or behaviors of new teachers, and transplanting theories into the classroom.

Studies on the effectiveness of training programs have shown that different programs provide different degrees of benefit for preservice teachers. Certain training programs achieve limited results in altering mismatched preconceptions (Lo, 2005; Peacock, 2001). An extensive investigation on the change in beliefs among preservice teachers showed that students tended to hold the same personal beliefs and self-images as a teacher before and after a training program (Kangan, 1992). The knowledge, practice, and supervision gained during training were 
apparently insufficient in changing these beliefs. To an extent, information acquired during the training process may actually confirm the students' preexisting beliefs and determine how they learn new knowledge (Richardson, 2003). When teaching in classroom settings, student teachers tended to use the methods and techniques they grew up with rather than those learned during their training program. To make matters worse, according to Korthagen and Russell (1999, p. 3), "Many notions and educational conceptions, developed during teacher education, were "washed out' during field experiences."

Studies on teacher training programs have shown the value of integrating specific theories into learning contexts where students can practice applying the theory. However, theories should not be introduced into contexts that are too tightly controlled or lack sufficient pupils, as the results are less effective under those conditions (Watzke, 2007). The opportunity to learn from real-life experience but being deprived of the opportunity for adequate reflection weakens the effect. In such cases, the transition from the learning process to the pedagogical routine remains unclear for the student (Hollingsworth, 1989). Many training programs provide insufficient pedagogical knowledge for prospective teachers (Kang, 1992; Zeichner \& Gore, 1990). The tendency of training programs to emphasize theoretical and philosophical issues creates a gap between theory and real-life knowledge and experience, a discrepancy that frustrates prospective teachers (Calderhead \& Shorrock, 1997). Studies such as the current one are required to investigate the process by which people learn to teach and the elements involved in this process; that is, courses or practices in the training program that assist along the way.

\section{The Study}

Descriptive studies describe the existing phenomena and discover potential research areas and connections that previous related studies overlook. Such studies focus on data collection during a specific time and at a specific place (Vogt, 1999). The current descriptive study adopts a qualitative paradigm and examines the learning process of a group of EFL teachers while conducting practicum at an elementary school.

\subsection{Context and Participants}

\subsubsection{Teaching Practicum}

Data from classroom observations were collected from the records of student teachers during their practicum. Classroom experiences constitute a major part of the training program we investigated. Students in the program were required to teach English to elementary school pupils once a week in the third year of the program. The teaching practicum lasted a year and involved cooperation between the training institute and the public elementary school in the same neighborhood. This cooperation allows student teachers to gain (a) experience in teaching English to elementary school pupils, and (b) classroom teaching experience. Each week, student teachers were required to plan and teach one English lesson beyond the content of the regular English class. They decided on the content themselves, and designed their own material to fit with the theme of the regular English class. The practicum generally was conducted on a Tuesday afternoon and lasted 40 minutes. Student teachers visited the elementary school to teach English during that time and returned to the university afterward. Mentor sessions with the university lecturer were held weekly. Moreover, group mentorship with other student teachers occurred every second week; these meetings provided the opportunity to discuss events and difficulties encountered in classroom teaching. At the end of the semester, English teachers at various elementary schools reviewed the recordings of the student teachers and offered their suggestions during a group meeting. Thus, student teachers were exposed to several sources of suggestions and feedback, and additional information on techniques and solutions.

During the practicum, the weekly routine for each student teacher included (a) developing lesson plans prior to the classes, (b) reflecting on the lesson by keeping a teaching journal, and (c) discussing the lesson with the instructor afterward. Student teachers were taught how to develop lesson plans at the beginning of the practicum. To enhance consistency among all student teachers, a single model lesson plan was provided as a sample to emulate. The model lesson plan consisted of several parts: lesson objectives, level of students, activities, props used, and lesson evaluation. To prompt reflection, the students were given a list of questions to answer about their own teaching, such as: "What did you learn from that event in class?" and "If you had a second opportunity, what would you do differently?" The university lecturer read and commented on the students' lesson plans and reflections each week before conducting the mentoring session.

\subsubsection{Participants}

For qualitative fieldwork, researchers draw a purposive sample to present various examined phenomena (Stake, 2000). Participants in this study represent student teachers of different genders and teaching experiences. Two male and two female student teachers were chosen in this study (Table 1). All were non-native English speakers 
with more than ten years of English learning experience. Their English proficiency varied, but was sufficient to teach elementary students. Three of them were in their early twenties and one male teacher was in his early thirties. Each of them had taught English in private settings, but their teaching experience was considerably limited. Each participant had personal involvement with children and their experience as an English teacher in language classroom varied. In terms of pedagogical knowledge, all of them had finished the required courses related to language teaching and learning and they continued taking two remaining core courses on language teaching methods and approaches during the time of the study.

Table 1. Ethnographic information of participants

\begin{tabular}{|c|c|c|c|c|}
\hline $\begin{array}{l}\text { Participants } \\
\text { Character }\end{array}$ & Jay & Joseph & Vicky & Kitty \\
\hline Age & 33 & 21 & 21 & 20 \\
\hline $\begin{array}{l}\text { Experience on } \\
\text { teaching English }\end{array}$ & $\begin{array}{l}1-\mathrm{yr} \\
\text { one-on-one } \\
\text { tutoring }\end{array}$ & & $\begin{array}{l}\text { 2-yrs part-time } \\
\text { teaching at private } \\
\text { language institutes } \\
3 \text {-yrs one-on-one } \\
\text { tutoring }\end{array}$ & $\begin{array}{l}\quad 1-y r \text { part-time } \\
\text { teaching at private } \\
\text { language institutes } \\
\text { 3-yrs one-on-one } \\
\text { tutoring }\end{array}$ \\
\hline $\begin{array}{l}\text { Other working } \\
\text { experience }\end{array}$ & $\begin{array}{l}\text { Work as a } \\
\text { government } \\
\text { official for } 5 \\
\text { years }\end{array}$ & $\begin{array}{l}\text { Work as an } \\
\text { assistant at } \\
\text { summer camps } \\
\text { for young } \\
\text { children }\end{array}$ & & \\
\hline $\begin{array}{l}\text { Levels taught } \\
\text { during the } \\
\text { practicum }\end{array}$ & $1^{\text {st }}$ grade & $2^{\text {nd }}$ grade & $2^{\text {nd }}$ grade & 1st grade \\
\hline
\end{tabular}

\subsection{Data Collection and Analysis}

This study explored the integration between learned knowledge and actual classroom teaching, and changes in the students' beliefs about teaching. Data from interviews, reflections, lesson plans, and classroom observations were collected and analyzed. Each data source was triangulated by two researchers to identify (a) changes in students' concerns and beliefs, (b) possible causes for the identified changes, and (c) difficulties encountered during the practicum. The data analysis followed the procedure of grounded theory; we used the techniques of open coding and axial coding to identify and make connections between themes and categories that emerged from the data. Themes concluded based on each directions were discussed by the two researchers until they reached consensus.

\subsubsection{Semi-structured Interviews}

The researchers interviewed each participant before, during, and after the practicum. Each interview lasted approximately one hour and a semi-structured schedule was used. We interviewed four students and transcribed the interview data before conducting the analysis. Interview questions were arranged in four different categories: (a) pedagogical beliefs, (b) teaching content/activities, (c) reflection on classroom teaching, and (d) life experience.

\subsubsection{Teaching Reflections and Lesson Plans}

The qualitative data analysis emphasized the types of activities included in students' lesson plans, and special events that occurred during teaching. Approximately 40 teaching reflections and lesson plans from each participant were collected and examined. In the teaching reflection, student teachers were guided to reflect upon unexpected events that occurred in the classroom and the manner in which they had handled those incidents. They discussed how they would plan and organize an activity if they had a second chance to teach the same content. In addition, lesson plans showed whether the students' preferences for activities and teaching props had changed. The teaching reflections showed how well students developed critical analytic skills regarding their own teaching and their ability to handle unexpected events.

\subsubsection{Classroom Observation}

Data gained from the interviews and teaching reflections were triangulated with direct observation in real classroom teachings. Every week, we video recorded one class from each grade. Thus, an average of two to three lessons per student teacher were recorded each semester. Six lessons for each participant were recorded and 
analyzed according to various aspects. We used a classroom observation sheet to note aspects of in-class teaching, such as the use of English or the type of learning activities presented. The information documented on the observation sheet helped to portray the students' implementation of pedagogical beliefs and their modifications of lesson plans, to adapt to the classroom reality. Certain sections of the classroom observation sheet required descriptions of events, and other sections required the observer to log the occurrence of specific situations. Two reviewers watched the teaching recordings together and each filled out a separate observation sheet. After this review, they discussed discrepancies to reach consensus.

\section{Results}

\subsection{Pedagogical Beliefs on the Qualification of English Teachers}

Questions regarding elements that promote learning English and the qualification of an English teacher were asked in interviews throughout the practicum period. We wanted to assess whether these aspects of the student teachers' thinking were altered during this period. No change was observed in their concepts of essential elements for learning English, but their beliefs about the qualification of teachers did change during the practicum.

Participants all stated that the opportunity to communicate in English in various contexts was important to learn the language. Pronunciation practice and activities or games where students could speak English were also mentioned by the majority of participants. However, of all the participants, only Vivian created a classroom atmosphere that directly reflected this belief. With her strong faith in the "immersion" approach to language learning, Vivian tried to create an environment in which her students could listen to and speak English. She wrote, "I want to make sure that I do not speak any Chinese in the class because students need to hear English but not Chinese" (10-17, teaching reflections). As a result, her class was unique because of the high proportion of English used in the instruction. All other participants conducted their classroom instruction mainly in Chinese, and the class activities comprised mechanical exercises using fixed patterns and words. And such classroom instruction is the traditional way of learning English in Taiwan. The discrepancy between Vivian's approach and that of the other students shows the potentially strong influence on teaching behavior gained from students' past experiences as language learners. The majority of participants taught in a manner that reflected their own memories of having learnt English at a young age.

When asked in the initial stage of the practicum about the training of English teachers, participants emphasized that training programs should provide knowledge (i.e. English proficiency and content) and cultural understanding (i.e. of countries in which English is spoken) as well as pedagogical knowledge (e.g. language teaching methods and child psychology). Several participants mentioned that personal qualities should be fostered by the training, including affective traits such as compassion toward students or the courage to stand in front of the classroom, and skills on classroom management. Jay stated that English proficiency, particularly oral ability, and teaching ability are lifelong pursuits that require consistent practice and new knowledge. He said, "Teaching in a real classroom can help accumulate teaching experience that is the most important of all. The same thing applies to English proficiency. Both of these two elements really need time and patience and cannot be achieved in the short term" (first interview).

Vivian considered the willingness to place oneself in a pupil's shoes and the confidence to stand in front of the class to be two crucial characteristics of a good English teacher. She also emphasized the necessity of theory in training English teachers. In the interview, she said, "The first and most important is theory [on language teaching/learning] because you understand the development and changes over history in language teaching through the study of theories. This is similar to standing on the shoulder of a giant and looking over it" (first interview).

Participants' opinions on English teacher training and qualifications reflected their views on professional knowledge and the manner in which a teacher presents themselves to a class. All participants wished to be seen as a patient and caring teacher. Thus, the initial emphasis was on the teacher. As the practicum continued, the focus shifted to interaction with the students and skills in dealing with students' needs. Kathy was evidently quite affected by her classroom teaching experience. Toward the end of the practicum, her ability to create appropriate props and handle unexpected events in the classroom became more important than the knowledge she had previously considered crucial (in the previous year). A similar change was mentioned by Joseph, who recognized that the ability to understand pupils' feelings was more important than English ability.

These changes in beliefs on teaching English suggested that the practicum enabled student teachers to realize that teaching English requires both professional and practical knowledge. The experience of interacting with pupils in a real classroom setting allowed novice teachers to appreciate that comprehending their students' needs 
and struggles was as important as English language proficiency.

\subsection{Changes and Difficulties during the Practicum}

Previous studies have shown that an encounter with conflict between previous beliefs and real life provides the catalyst for teacher development. The most commonly affected area was classroom activities. Each participant carries their understanding of and beliefs on learning of young learners from various memories on this particular group of student teachers. The student teachers' past learning experiences also shaped their design of classroom activities and their interaction with pupils. Idealized and inappropriate beliefs have to be confronted when teaching in a real classroom. Such changes typically result in a greater understanding of pupils and a more mature comprehension of one's position as a teacher. Change typically occurs when the student teacher notices something "different" in their classroom. These differences contradict with the teacher's beliefs and catch their attention. For example, Jay's teaching reflections and classroom observations during the first half of the practicum showed relatively limited signs of engagement with pupils in classroom activities. However, in his third interview, Jay stated that

My teaching in the first semester was pretty much a repetition of the same pattern: review, new lessons, and then review again. I felt the boredom from the eyes of my students. But, then in the second semester, students' excitement caught my attention after playing games... I continued to include different games into my lesson plan every week... lessons have to be creative to motivate students.

After discussions with other student teachers, Jay realized that he had been ignoring the learning style of his students who were fun seekers. He had believed that classroom activities should include as many practices and drills as possible. The classroom observations highlighted the change in his attitude, as Jay was observed to smile more often in the second semester, and engaged in more games. He began to understand the different needs of his students and the typical learning styles for each age group.

Similar findings were evident in Vivian's case as she began to choose more static classroom activities. In the first interview, when talking about her design of classroom activities, she said: "... [I] tried to modify the activities learned in the school club... play several games from my childhood." Initially, pupils in her class constantly moved around the classroom or outside in the playground, and Vivian engaged them with numerous songs and games. Gradually, her use of activities requiring physical action decreased. Toward the end of the second semester, she realized that activities that did not require students to move physically in the classroom could be equally effective. She wrote: “... this time I realize that dancing or moving around is not the only way to teach young children; writing and drawing are also good ideas! I was also able to better control the whole class when everyone was sitting in their seat." (teaching log; March 18th ).

Changes in classroom activities and interaction indicated a growing understanding of pupils' feelings and needs. For Vivian and Kathy, this understanding also led to the development of critical thinking. Both these student teachers were able to look beyond their responsibilities as practicum teachers, and reflect upon their contribution to their pupils and the education system overall. Toward the end of the first semester, Vivian wrote:

I usually think about one question: What can I teach my students? I only have one hour each week to interact with them and it takes time to build a relationship. With such limited time, how can I make my teaching as influential as possible? I believe, instead of teaching them English, it might be more helpful for them if I teach them the correct attitude toward learning and build their interest in English and the related culture (teaching log; December 18th ).

Vivian began to expand her responsibility as a teacher beyond the focus on transmitting linguistic knowledge to her students. She wanted to make a difference in the pupils' learning process.

Kathy similarly witnessed the pupils' struggles and noticed an inequality. In the final interview, she spoke of the wide range of English proficiency among her students. She said, “... I feel for my students. At such a young age, some of them need to attend cram school after getting out of elementary school. Others are so eager to learn English, but their family cannot afford after-school language schools. I think something needs to be done to change it" (third interview).

Student teachers also showed a change in their approach to challenges that they encountered in the classroom. Participants frequently faced the dilemma of how to control students' behavior effectively. Relatively experienced teachers, such as Vivian and Kathy, seldom addressed this concern in their teaching reflections or interviews. Students in their classes were indeed more effectively controlled and disciplined. However, the two male student teachers, especially Joseph, encountered greater challenges in dealing with pupil misbehavior. Joseph's classroom observations showed that his provision of rules on punishment and reward was unclear. 
Students often walked around the classroom without appropriate control, and Joseph's classes tended to be chaotic. He complained of the difficulties in handling student misbehavior several times in his interviews. For example, he stated that "I am most troubled by classroom order. The entire class is in chaos and students like to talk to each other when I am teaching. I ask them to be quiet, but they go back to the 'talking mode' in seconds! I am really frustrated to see it" (second interview).

Another common problem emerged in our study. This struggle did not result in changes on the part of student teachers, but led instead to a sense of hopelessness. The problem can be referred to as the "double peak" phenomenon that is frequently encountered in Taiwan, which describes the significant discrepancy in pupils' English proficiency within a single class. Many Taiwanese parents have been deeply influenced by and follow the idea of the Critical Period Hypothesis. According to this theory, the earlier a child is exposed to English, the better. Consequently, numerous Taiwanese children begin their English learning at a young age. In response to the demand, a large number of kindergartens and private language institutes have been created, presenting a huge volume of learning material. However, many scholars and language educators oppose this practice. Nonetheless, learning English at a young age has become the norm in Taiwan and the growth of this field has been sensational. Unfortunately, behind this sensation is the untold story of stressed children whose lives are out of their own control. At the same time, teachers face the difficulty of choosing material that is appropriate for a specific student level.

\section{Discussion}

\subsection{Difficulties during the Practicum}

The ability to manage students in the classroom is the most painful and struggled component to every student teacher during the practicum period. Past experience with young children determines how much the student teacher would be troubled by students' behavior in the classroom. Problems in classroom management come from insufficient understanding of young children and the role as a teacher. Student teachers do not recognize their significant role as an authority figure and young learners' ways of learning when first stepping into the classroom. During the process of classroom teaching, pupils act as "critical reality definers" (Tang, 2003) and the comprehension of the nature, needs, and difficulties of students' learning validate and modify pedagogical competence and the image of teachers of student teachers. Teachers without a clear image of themselves as teachers in the initial stage of learning fail to integrate classroom management and instruction and establish a procedure that would further hinder transformation of the self-conscious to more automatic and unconscious teaching (Hollingsworth, 1989; Kangan, 1992). Consequently, methods on helping students in teacher training program be aware of their roles and authority as teachers are important in course design and teaching practice. Only when the teacher is fully aware of his unique power and responsibility in a classroom, the training they receive in the teacher program could make impact in the journey of teacher development.

\subsection{Beliefs and Concerns in Teaching}

The development of teacher knowledge of this group of student teachers in the current study shows shift on attentions and concerns from self-image and teaching techniques to the struggles and needs of students. They gradually reflect upon the model they set up in front of students and the impact they could make during the practicum period. What is observed in the current study echo Kangan's (1992) model of teacher development which emphasizes the changes on metacognitive skill and the awareness of the flexibility of teacher knowledge and skills. It cannot be denied that student teachers in the current study do not develop the problem solving skill that could be generated over different contexts. Nevertheless, the integration of theory course and real classroom teaching indeed bring some changes in student teachers' beliefs.

However, the force that contributes to such changes is the interaction with the teaching contexts, such as fellow student teachers, or information found in Cyberspace. The information from training program, including mentoring session, does not contribute to these changes. For example, in recent decades, learning English as an acquired tool to accomplish tasks in daily routines has become the core concept in EFL contexts. The importance of communicative competence is repetitively mentioned and reinforced in theory courses. However, classroom observations of classroom teaching did not show obvious traces of implementing such concept. Vivian was the only teacher to give students chances to use language freely. She also tried very hard to use English when giving commands or instructions. Other participants, however, were more comfortable with the teacher-centered mode where student responses were limited to the repetition of either teachers' demonstrations or expressions written in the textbook.

Such a discovery indicates that this group of student teachers only understood this concept at the surface level, but did not know how to apply this concept into classroom teaching. As suggested in previous studies (Kangan 
1992; Richardson, 2003), student teachers tend to adopt their own personal experiences, but not new concepts learned in the training program as the point of reference when designing lessons. In other words, they select partial learned theories or concepts to confirm, but not to change, their beliefs and teaching practice (Korthagen, \& Russell, 1999). As Hennissen et al. (2001) claim "teachers' knowledge and skills are event-structured, context-based, and practice-oriented in nature" (p. 1051). The specific environment in which student teachers work as the context that influences the development of pedagogical beliefs. Results of the current study indicate the change of beliefs relate to classroom practice and usually occur when the student teachers encounter unexpected event that create conflict between preconception and reality. The classroom discussions and lectures in training program do not challenge student teachers so much that they need to make changes. But the classroom teaching forces student teachers to re-examine and reconstruct their beliefs and make changes accordingly. And this real world experience even enhances the development of critical reflective teaching in two participants.

Student teachers in the current study were coincidently concerned with whether their corrections or comments would hurt students' feelings. They tended to pay more attention on building loving images of themselves to students than on the effect their teaching made on student learning. As suggested in the Concerns Theory (Fuller, 1969), the concern for self and teaching tasks are the first two stages in this developmental process. Concerns found in the current study indeed echoed this theory. However, Fuller suggested that these stages follow a chronological and hierarchical order and teachers enter the stage of effect and reflect on their challenges and stimulation to students' learning until accumulating a certain amount of teaching experience. However, student teachers in the current study did not necessarily follow what Fuller suggested. Concerns from both Vivian and Kathy reached broader school contexts and related to the social-economic status of students. Vivian stated that the goal of English teaching should go beyond simply English language knowledge to achieving a more mature and active attitude of learning in general. Kathy even discussed the inequality she observed among her students and the concerns on the results of such a phenomena effect.

\subsection{Influence from the Training Program}

Teacher training programs aim at transforming student teachers' inappropriate or immature beliefs into appropriate and mature capabilities. The effectiveness of a teacher-training program is shown in its influence on the change in beliefs and teaching practices of perspective teachers, particularly at the initial stage of teaching practice. The influence of the training program is noticeable when student teachers feel confused in adopting theories and concepts discussed in the lecture room or mentoring sessions. Thus, the awareness of the difference between theory and reality can be a sign of an effective training program.

However, this study showed that student teachers were also influenced by the Internet, past learning experiences, discussions with other student teachers, and their own self-monitoring. Surfing the Internet and consulting homeroom teachers and peer student groups constituted the two main sources of suggestions or solutions in our study group. Moreover, every student teacher emphasized the importance of motivation and communication, two concepts commonly discussed in the mentor and course sessions. Nonetheless, the influence of peers and the Internet as well as the novice teacher's own previous experience as a learner overshadowed these formal influences.

Knowledge learned and discussed in the training program did not exert a noticeable effect on classroom teaching, for any of the student teachers in this study. Two of the student teachers did not even mention the training program during their practicum. The only trace of an effect from the formal courses appeared in the activities at the start of the practicum. In the initial stage of the practicum, student teachers frequently employed the method of "total physical response". This technique requires minimal experience to master and is suitable to the learning styles of young children. The students in our study were indeed teaching young children. This teaching method is commonly used by English teachers in Taiwan.

Previous studies have shown that mentoring influenced student teachers (Lindgren, 2005; Marable \& Raimondi, 2007), but our findings did not confirm this. Instead, we found evidence of resistance arising from deep-seated or long-lasting beliefs (Korthagen \& Russell, 1999). These results cast doubt on the effectiveness or necessity of the theory lectures and discussions that have traditionally formed a large portion of teacher training. However, previous studies have also shown that acceptance of new information can lead to a change in a student's belief system. This type of change has been associated with several elements of the training program, including challenges encountered (Pajares, 1992), the contrast between various bodies of culturally-related knowledge, the teacher's personality (Eilam, 2002), and situations that directly test one's former beliefs (Fischl \& Sagy, 2005). The integration of theory and practice discussed by Brouwer (1989), in which student teachers encounter reality 
and challenges, was indeed evident in our study. Nevertheless, the mere awareness of conceptual differences does not lead automatically to the acceptance of new information and theories. Student teachers' resistance to or ignorance of theories discussed in the training program remained strong throughout the practicum. Our findings showed that student teachers tended to adopt the teaching method they had been exposed to as children or youngsters rather than the methods learned in their formal training.

The main reason to explain such resistance relies on the differences between the local teaching contexts and Western-generated theories. Teaching methods and techniques taught in training program are popular and well-established in the learning contexts that differ from the contexts of the participants culturally and pedagogically. Participants tended to question the feasibility of teaching methods and techniques learned in the course work. The teaching reflections noted by Jay and Vivian revealed the students' concerns and caution in adopting Western methods and techniques such as the communicative approach or group work. Consequently, these teaching methods were not commonly seen in the classroom observations. It is possible that our study participants found that Western theories lacked applicability to their own culture and values, and that this deficiency would be detrimental to their pupils. Such theories are incompatible with students' preferred styles of learning and their social, religious, or community values (Liyanage \& Bartlett, 2008). The introduction of textbook knowledge of language teaching methods should be prefaced by a discussion of local knowledge and customs (Xu \& Connelly, 2009). Western teaching methods are not always applicable to non-Western contexts and the validity of each method in a local setting should be assessed (Chiang, 2008; Eilam, 2002). Learning to teach is context-specific and culturally bound. Teacher training programs must consider the educational and philosophical values of the specific group of pupils the perspective teachers will face. Thus, in addition to propounding theories developed in the West, the training of Taiwanese teachers requires attention to issues and techniques that have proven to be suitable for local students.

\section{Conclusion}

The current study unveils the process of becoming an English teacher and changes during the initial stage. Results from this study raise some concerns over student teachers' acceptance of Western-made theories into classroom teaching and imply factors that lead to smoother journey in this stage. Data indicate the less desirable effect from the training program and the powerful role that past learning experiences and peer student teachers play in this stage. One crucial factor that determines the success of this stage is if the student teacher builds a clear image as a teacher in front of pupils. A failure to do so creates potential obstacles in classroom management. Results from this study suggest the need to integrate group mentor sessions, besides practicum, as a platform where student teachers could exchange information, solutions, and most important of all, comfort from someone who are in the same boat. Discussions with peer student teachers also show some level of effect on changes of teaching beliefs. Moreover, methods to establish appropriate self-image as a teacher should be a main concern in teacher education since it is a crucial factor to classroom management to student teachers. In conclusion, to both novice and experienced teachers, teaching is an endless learning process that consists of self-searching and mutual support. Future studies should address issues on the process of apprenticeship between novice and experienced teachers, particularly its effect in handling teacher stress and burnout.

\section{References}

Begle, E. G. (1979). Critical variables in mathematics education: Findings from a survey of the empirical literature. Washington, DC: Mathematical Association of America.

Bransford, J., Darling-Hammond, L., \& LePage, P. (2005). Introduction. In L. Darling-Hammond, \& J. Brandsford (Eds.), Preparing teachers for a changing world: What teachers should learn and be able to do (pp. 1-40). San Francisco: Jossey-Bass Press.

Brouwer, C. N. (1989). Integrated teacher education, principles and effects. Amsterdam: Brouwer Press.

Busch, D. (2010). Pre-service teacher beliefs about language learning: The second language acquisition course as an agent for change. Language Teaching Research, 14, 318-337. http://dx.doi.org/10.1177/1362168810365239

Calderhead, J., \& Shorrock, S. B. (1997). Understanding teacher education. Washington D.C.: The Falmer press.

Chan, K. W., \& Elliott, R. G. (2004). Relational analysis of personal epistemology and conceptions about teaching and learning. Teaching and Teacher Education, 20, 817-831. http://dx.doi.org/10.1016/j.tate.2004.09.002

Chiang, M. (2008). Effects of fieldwork experience on empowering prospective foreign language teachers. Teaching and Teacher Education, 24, 1270-1287. 
Eilam, B. (2002). "Passing Through" a Western-democratic teacher education: The case of Israeli Arab teachers. Teachers College Record, 104, 1656-1701. http://dx.doi.org/10.1111/1467-9620.00216

Fischl, D., \& Sagy, S. (2005). Beliefs about teaching, teachers, and schools among pre-service teachers: The case of Israeli-Bedouin students. Language, Culture and Curriculum, 18, 59-71. http://dx.doi.org/10.1080/07908310508668733

Fuller, F. F. (1969). Concerns of teachers: A developmental conceptualization. American Educational Research Journal, 6, 207-226.

Goldhaber, D. D., \& Brewerm, D. J. (2000). Does teacher certification matter? High school teacher certification status and student achievement. Educational Evaluation and Policy Analysis, 22, 129-145.

Hennissen, P., Crasborn, F., Brouwer N., Korthagen, F., \& Bergen, T. (2011). Clarifying pre-service teacher perceptions of mentor teachers' developing use of mentoring skills. Teaching and teacher education, 27, 1049-1058. http://dx.doi.org/10.1016/j.tate.2011.03.009

Hollingsworth. S. J. (1989). Prior beliefs and cognitive change in learning to teach. American Educational Research Journal, 26, 160-189.

Hwang, Y. H. (1996). Student Teachers' Pedagogical Content Knowledge in Elementary Mathematics: A case study. Unpublished Master's Thesis, National Hsinchu Teachers College. Hsinchu, Taiwan.

Kangan, D. M. (1992). Professional growth among preservice and beginning teachers. Review of Educational Research, 62, 129-169.

Korthagen, F., \& Russell, T. (1999). Building Teacher Education on what we know about teacher development. Paper presented at the Annual Meeting of the American Educational Research Association.

Leu, Y. J. (1997). Professional Growth of Secondary Biology Student Teachers' Teaching: A Case Study. Unpublished Master's Thesis, National Taiwan Normal University. Taipei, Taiwan.

Lin, M. (2008, March). Early childhood teachers' beliefs and practices of anti-bias curriculum. Paper presented at the Annual Meeting of the American Educational Research Association, New York.

Lin, M., \& Lucey, T. A. (2010). Individual and group reflection strategies what we learned from preservice teachers. Multicultural education, 51-54.

Lindgren, U. (2005). Experiences of beginning teachers in a school-based mentoring program in Sweden. Educational Studies, 21, 251-263. http://dx.doi.org/10.1080/03055690500236290

Liyanage, I., \& Bartlett, B. J. (2008). Contextually responsive transfer: Perceptions of NNES on an ESL/EFL teacher training programme. Teaching and Teacher Education, 24, 1827-1836. http://dx.doi.org/10.1016/j.tate.2008.02.009

Lo, Y.-H. G. (2005). Relevance of knowledge of second language acquisition: An in-depth case study of a non-native EFL teacher. In N. Bartels (Ed.), Applied linguistics and language teacher education (pp. 85-102). New York: Kluwer Academic.

Marable, M., \& Raimondi, S. (2007). Teachers' perceptions of what was most (and least) supportive during their first year of teaching. Mentoring \& Tutoring: Partnership in Learning, 15, 25-37.

Melnick, S., \& Meister, D. (2008). A comparison of beginning and experienced teachers' concerns. Educational Research Quarterly, 31, 39-56.

Pajares, M. F. (1992). Teacher beliefs and educational research: cleaning up a messy construct. Review of Educational Research, 14, 5-19.

Peacock, M. (2001). Pre-service ESL teachers' beliefs about second language learning: A longitudinal study. System, 29, 177-95.

Richardson, V. (2003). Preservice teachers' beliefs. In J. Raths, \& A. McAninch (Eds.), Teacher beliefs and teacher education: Advances in teacher education (pp. 1-22). Greenwich, CT: Information Age Publishers.

Stake, R. E. (2000). Case Study. In Handbook of Qualitative Research (pp. 435-455). London: Sage Publications, Inc.

Tang, S. Y. F. (2003). Challenge and support: the dynamics of student teachers' professional learning in the field $\begin{array}{lllll}\text { experience. Teaching } \quad \text { and } & \text { 4eacher }\end{array}$ http://dx.doi.org/10.1016/S0742-051X(03)00047-7 
Vogt, W. P. (1999). Dictionary of statistics and methodology: A nontechnical guide for the social science. London: SAGE Publications.

Watzke, J. (2007). Longitudinal research on beginning teacher development: Complexity as a challenge to concerns-based stage theory. Teaching and Teacher Education, 23, 106-122.

Wilson, S. M., Floden, R. E., \& Ferrini-Mundy, J. (2001). Teacher preparation research: Current knowledge, gaps, and recommendations: A research report prepared for the U.S. Department of Education. Seattle, WA: Center for the Study of Teaching and Policy.

Xu, S., \& Connelly, M. (2009). Narrative inquiry for teacher education and development: Focus on English as a foreign language in China. Teaching and Teacher Education, 25, 219-227. http://dx.doi.org/10.1016/j.tate.2008.10.006

Zeichner, K. M., \& Gore, J. M. (1990). Teacher socialization. In W. R. Houston (Eds.), Handbook of search on teacher education (pp. 329-348). New York: Macmillan. 